\title{
Efficacy of an Exclusive Transcanal Endoscopic Ear Surgery for Congenital Cholesteatoma
}

\author{
Abdulrahman K Aledan* and Ebraheem A Alnofal \\ Department of Otolaryngology, King Saud Medical city, Riyadh, Saudi Arabia
}

Submission: September 03, 2019; Published: September 25, 2019

*Corresponding author: Abdulrahman K Aledan, Department of Otolaryngology, King Saud Medical city, Riyadh, Saudi Arabia

Abstract

Background: Congenital cholesteatoma is a type of cholesteatoma; it is a defect developed during embryonic stage and occur by entrapped of the epithelia in the middle ear cleft Endoscopic approach recently was used for the mastoid and middle ear. Development in endoscopy has been performed.

Aim: To investigate the ability to use endoscopic ear surgery exclusively for congenital cholesteatoma.

Methods: Searching process in the Pubmed database was performed to obtain articles related to our subject. Several keywords were used to obtain all possible articles. The included articles were chosen according to specific criteria.

Results: There were nine articles included in this article review as they met the inclusion criteria and 21 articles were excluded. The results of the articles were summarized according to the main titles in the table.

Conclusion: Endoscopic ear surgery is a successful exclusive strategy for the management of pediatric congenital cholesteatoma.

Keywords: CC; CC management; Endoscopy; Pediatrics

\section{Introduction}

Cholesteatoma is the growth of abnormal keratinizing squamous epithelium with the combination of cystic lesions, cystic mass with surrounding inflammatory reaction, keratin debris, three-dimensional structure, middle ear tumor, epidermic cyst and form of chronic otitis media [1-10]. Cholesteatoma is classified primarily into acquired and congenital [11]. Acquired cholesteatoma (AC) is divided into primary and secondary types according to the migration of the epithelium into the middle ear and presence of perforation $[6,11]$.

Whereas congenital cholesteatoma (CC) is a defect developed during embryogenesis when the epithelial rest become entrapped in the middle ear cleft [12]. In other word, CC is described by its presence in the middle ear cavity [12]. Clinical presentation of CC is based on the extent and location of the lesion [13]. CC is characterized by white mass medial to the tympanic membrane, abnormal otoscopic examination, conductive hearing loss and ear pain as well as neck pain. However, this pain rarely occurs $[13,14]$. Otorrhea and otalgia are rare, whereas $50 \%$ of patients had a history of previous otitis media episodes [15]. The prevalence of CC is low ranging between $2 \%$ to $5 \%$ of cholesteatomas [16]. However, the higher prevalence range among children was estimated to be $4 \%$ to $24 \%$ of all cholesteatoma's cases [17].

Staging systems were established to enhance and increase the treatment outcomes in CC children patients; there are two staging systems proposed [18-20]. The staging system by Nelson et al. [19] involves two types of CC, type 1 which involves the middle ear with ossicular involvement, whereas type 2 involves ossicular involvement defined as ossicular erosion or removal of ossicles due to disease. The staging system by Potsic et al. [18] involves four stages of CC, stage 1 refers to a single-quadrant disease, whereas stage 2 and 3 involves disease in multiple quadrants and ossicular involvement respectively, whereas the fourth stage of the disease is defined when the disease is any mastoid extension. Surgery is the treatment of CC, and the goal of this treatment is to remove the disease completely with the restoration of hearing, the conventional treatment includes canal wall down or intact canal wall combined with tympanoplasty [21].

Recently, endoscopic approach to the mastoid and middle ear was used by several investigators to reduce the morbidity of s second look operation [22]. Endoscopy became available 


\section{Global Journal of Otolaryngology}

in Europe in the late 1970s for evaluation of patients 'ears and rarely for diagnostic purpose in operation rooms [23]. The first endoscopically guided surgery was performed in 1987 in France to prevent residual cholesteatoma [24]. The reduction of morbidity and increase in surgical procedure accuracy were achieved using endoscopy [25]. The role of the endoscope in the management of cholesteatoma, especially in pediatric patients has been developed [26-28]. The endoscope was used combined with a microscope resulting in a lower rate of residual disease [28].

Moreover, the endoscope was incorporated as the primary method for visualizing the operative field during surgical dissection of cholesteatoma from the middle ear [29]. Several advantages of endoscopic ear surgery in pediatric patients were reported by Tarabichi, and they included a dynamic and broad view of the middle ear with the ability to "see around corners," improved visualization reduction in the postauricular incision and dissection rates [30]. However, several drawbacks were stated, and they included potential increased initial surgical times and cost, the loss of binocular vision as well as a learning curve to master one-handed endoscopic surgical technique [29].
The present article review was conducted to investigate if the endoscopic ear surgery can be exclusive for CC.

\section{Materials and Methods}

This article review is presented to investigate if endoscopic ear surgery can be exclusively used for CC by reviewing previous articles. The search process was performed using the Pubmed database and several keywords to obtain related articles including" Congenital Cholesteatoma, CC management, Endoscope, Endoscopic ear surgery". We obtained 30 articles, which were selected according to specific criteria, these criteria include Congenital Cholesteatoma mainly, exclusive use of endoscopic surgery, follow up after surgery and include recurrence, residual disease, audiology and complications and pediatric patients however any age group can be included, the exclusion criteria included pure use of microscopic ear surgery and only use of endoscopic for assessing microscope ear surgery without comparing. After reviewing abstracts of the articles and according to criteria chosen, only nine articles were included, and the other articles were excluded. The publication years of included articles were between 2018 to 2008.

\section{Results}

Table 1: Author and publication year, study design, number of patients and main characteristics, cholesteatoma type/ classification, endoscopic strategy and follow up as well as results and main findings.

\begin{tabular}{|c|c|c|c|c|c|}
\hline $\begin{array}{l}\text { Author and Pub- } \\
\text { lication Year }\end{array}$ & Study Design & $\begin{array}{l}\text { Number of Patients } \\
\text { and Main Character- } \\
\text { istics }\end{array}$ & $\begin{array}{l}\text { Cholesteatoma } \\
\text { Type/ Classifica- } \\
\text { tion }\end{array}$ & $\begin{array}{l}\text { Endoscopic Strategy and } \\
\text { Follow Up }\end{array}$ & Results and Main Findings \\
\hline \multirow{4}{*}{ Park et al. [31] } & \multirow{4}{*}{$\begin{array}{l}\text { Retrospective } \\
\text { review }\end{array}$} & \multirow{4}{*}{$\begin{array}{c}25 \text { pediatric patients } \\
\text { with CC, whose age } \\
\text { range was } 17 \text { months to } \\
9 \text { years }\end{array}$} & ${ }^{*}$ Stage I:13 patients & $\begin{array}{c}\text { Transcanal endoscopic ear } \\
\text { surgery (TEES) by experienced } \\
\text { surgeon }\end{array}$ & $\begin{array}{l}\text { * No surgical complications } \\
\text { occurred }\end{array}$ \\
\hline & & & *Stage II:7patients & -Follow up for 24 months & $\begin{array}{l}* \text { Recurrence occurred for one } \\
\text { case with stage II }\end{array}$ \\
\hline & & & *Stage III:3patients & & $\begin{array}{l}\text { * Ossicular reconstruction was } \\
\text { performed for } 2 \text { patients whose } \\
\text { stage was II }\end{array}$ \\
\hline & & & & & $\begin{array}{c}{ }^{*} \text { CC limited to middle ear cavity } \\
\text { could be removed successfully } \\
\text { by TEES in all patients. }\end{array}$ \\
\hline \multirow{6}{*}{ Kim et al. [32] } & \multirow{6}{*}{$\begin{array}{l}\text { Retrospective case } \\
\text { review }\end{array}$} & \multirow{6}{*}{$\begin{array}{c}12 \text { children with CC } \\
\text { involving anterior sur- } \\
\text { face of the malleus and } \\
\text { tensor tympani (ASMT), } \\
\text { whose age range } 2-10 \\
\text { years }\end{array}$} & *Stage I: 8patients & TEES for 3 patients & $\begin{array}{l}\text { *ASMT was well visualized by } \\
\text { endoscope assistance in all cases }\end{array}$ \\
\hline & & & *Stage II:2 patients & $\begin{array}{l}\text {-Endoscopic assisted surgery } \\
\text { for } 9 \text { patients }\end{array}$ & *No hearing deterioration at 3 \\
\hline & & & *Stage II:2 patients & $\begin{array}{l}\text { - Follow up mean duration } 15.5 \\
\text { months }\end{array}$ & months after surgery \\
\hline & & & & & $\begin{array}{l}{ }^{*} \text { No residual or recurrent dis- } \\
\text { ease during the follow-up period }\end{array}$ \\
\hline & & & & & * No complications \\
\hline & & & & & $\begin{array}{c}\text { *Endoscopic ear surgery should } \\
\text { be considered in patients with } \\
\text { CC in the ASMT }\end{array}$ \\
\hline
\end{tabular}


Global Journal of Otolaryngology

\begin{tabular}{|c|c|c|c|c|c|}
\hline \multirow{6}{*}{$\begin{array}{l}\text { Ghadersohi et al. } \\
{[29]}\end{array}$} & \multirow{6}{*}{$\begin{array}{l}\text { Retrospective case } \\
\text { series }\end{array}$} & $\begin{array}{c}65 \text { pediatric } \mathrm{C} \text { cases in } \\
38 \text { ears }\end{array}$ & \multirow{6}{*}{ * Not mentioned } & $\begin{array}{c}\text { *Endoscope ear surgery (EES) } \\
\text { was performed for } 34 \text { patients } \\
\text { (38 ears) }\end{array}$ & $\begin{array}{l}{ }^{*} \text { Surgical time was longer for } \\
\text { acquired cases (226 min Vs } 154 \\
\text { min) }\end{array}$ \\
\hline & & $\begin{array}{l}\text { *Acquired } \mathrm{C}=27 \text { ears } \\
\text { (age mean } 10.9 \text { years) }\end{array}$ & & $\begin{array}{l}\text {-Endoscope was used as the } \\
\text { primary visualization tool in } \\
31 \text { ears }\end{array}$ & $\begin{array}{c}\text { *Recurrence in } 5 \text { ears, residual } \\
\text { disease in } 4 \text { ears ( } 3 \text { acquired and } \\
1 \text { congenital) }\end{array}$ \\
\hline & & $\begin{array}{c}* \mathrm{CC}=11 \text { ears (age mean } \\
\text { 3.8years) }\end{array}$ & & $\begin{array}{l}\text { - Endoscope was used as an } \\
\text { adjunct to the microscope in } \\
\text { seven ears }\end{array}$ & $\begin{array}{c}\text { * Hearing outcomes were com- } \\
\text { parable for both cholesteatoma } \\
\text { types. }\end{array}$ \\
\hline & & & & -TEES for 22 years and 35 cases & $\begin{array}{l}\text { * The lowest rates of recurrent } \\
\text { and residual disease were seen } \\
\text { in EES } 3 \text { cases }\end{array}$ \\
\hline & & & & $\begin{array}{l}\text {-Follow up for } 2.6 \text { years ( } 9 \\
\text { months to } 4.6 \text { years) }\end{array}$ & $\begin{array}{l}\text { * Low rates in EES } 2 \text { and } 3 \text { ears, } \\
\text { including four recurrences and } \\
\text { two ears with residual disease }\end{array}$ \\
\hline & & & & & $\begin{array}{l}\text { * The endoscopes are a viable } \\
\text { tool for resection of pediatric } \\
\text { cholesteatoma and provide } \\
\text { excellent visualization of the } \\
\text { middle ear and associated } \\
\text { recesses. }\end{array}$ \\
\hline \multirow{4}{*}{$\begin{array}{l}\text { Machiono et al. } \\
\text { [33] }\end{array}$} & \multirow{4}{*}{$\begin{array}{l}\text { Retrospective chart } \\
\text { and surgical video } \\
\text { review of patients } \\
\text { with bilateral con- } \\
\text { genital cholesteato- } \\
\text { ma (BCC) }\end{array}$} & \multirow{4}{*}{$\begin{array}{c}6 \text { pediatric patients with } \\
\text { BCC with a median age } \\
\text { of } 4 \text { years (range: } 2-7 \\
\text { years) }\end{array}$} & \multirow{4}{*}{${ }^{*}$ Not mentioned } & $\begin{array}{l}\text { Transcanal endoscopic ap- } \\
\text { proach (TEA) was performed } \\
\text { for } 6 \text { ears }\end{array}$ & $\begin{array}{l}* \text { No complications in any } \\
\text { patients }\end{array}$ \\
\hline & & & & $\begin{array}{c}\text { - microscopic post auricular } \\
\text { tympanoplasty was performed } \\
\text { for } 2 \text { ears }\end{array}$ & $\begin{array}{l}\text { * The endoscope allows good } \\
\text { surgical control of choleste- } \\
\text { atoma removal from hidden } \\
\text { recesses. }\end{array}$ \\
\hline & & & & $\begin{array}{l}\text {-Canal wall up mastodiectomy } \\
\text { for } 4 \text { ears }\end{array}$ & $\begin{array}{l}* \text { The TEA can have a valuable } \\
\text { role in BCC }\end{array}$ \\
\hline & & & & $\begin{array}{l}\text { - Follow up mean duration } 54.5 \\
\text { months }\end{array}$ & \\
\hline \multirow{6}{*}{ Cohen et al. [34] } & \multirow{6}{*}{$\begin{array}{l}\text { Case series with } \\
\text { chart review }\end{array}$} & $\begin{array}{c}55 \text { pediatric patients (56 } \\
\text { ears) with median age } \\
\text { of } 77 \text { years and range of } \\
6.7-13 \text { years }\end{array}$ & *Stage I:7 & $\begin{array}{l}\text { Endoscopes (EES) were used } \\
\text { for inspection in } 25 \text { primary } \\
\text { resections and for dissection in } \\
39 \text { primary resections. }\end{array}$ & $\begin{array}{l}\text { * Extent of disease at the time of } \\
\text { primary resection was similar } \\
\text { among groups }\end{array}$ \\
\hline & & $\begin{array}{l}\text { Patients were divided } \\
\text { into inspection group } \\
\text { (24) and dissection } \\
\text { group (32) }\end{array}$ & *Stage II : 8 & $\begin{array}{l}\text {-Follow up duration wasn't } \\
\text { mentioned, but it wasn't long }\end{array}$ & $\begin{array}{l}* \text { Rate of mastoidectomy signifi- } \\
\text { cantly decreased from } 63 \% \text { to } \\
33 \% \text { over the study period with } \\
\text { no significance }(\mathrm{P}=.04) \text { with } \\
\text { similar disease extent }\end{array}$ \\
\hline & & & *Stage III: 25 & & $\begin{array}{l}\text { * There was no significant differ- } \\
\text { ence in residual disease between } \\
\text { those performed EES for inspec- } \\
\text { tion and for dissection. }\end{array}$ \\
\hline & & & *Stage IV : 16 & & $\begin{array}{l}\text { * Residual cholesteatoma rates } \\
\text { during planned second-look pro- } \\
\text { cedures were similar between } \\
\text { the study groups. }\end{array}$ \\
\hline & & & & & $\begin{array}{l}\text { * Use of the endoscope led to a } \\
\text { lower rate of mastoidectomy }\end{array}$ \\
\hline & & & & & $\begin{array}{c}\text { for cases with similar disease } \\
\text { extent. }\end{array}$ \\
\hline
\end{tabular}




\begin{tabular}{|c|c|c|c|c|c|}
\hline \multirow{6}{*}{ Hunter et al. [26] } & \multirow{6}{*}{$\begin{array}{l}\text { Case series with } \\
\text { chart review }\end{array}$} & $\begin{array}{c}66 \text { patients (76 ears) } \\
\text { who underwent cho- } \\
\text { lesteatoma (range } 4-18 \\
\text { years) }\end{array}$ & \multirow{6}{*}{ * Not mentioned } & $\begin{array}{l}\text { Micoscopic removal of choleste- } \\
\text { atoma: } 74 \text { ears }\end{array}$ & $\begin{array}{l}\text { *Though second-look proce- } \\
\text { dures occurred in } 15 \text { endoscopic } \\
\text { cases and } 10 \text { microscopic cases } \\
(\mathrm{P}=.006)\end{array}$ \\
\hline & & $\begin{array}{l}\text { removal with either en- } \\
\text { doscopic or microscopic } \\
\text { visualization }\end{array}$ & & $\begin{array}{l}\text {-Endoscopic+Microscopic } \\
\text { removal: } 29 \text { ears }\end{array}$ & $\begin{array}{l}\text { *The rate of residual disease } \\
\text { didn't significantly differ in en- } \\
\text { doscopic and microscopic cases } \\
(20.0 \% \text { and } 40.0 \%) \text { respectively }\end{array}$ \\
\hline & & $\begin{array}{l}\text { with mean age of } 10.9 \\
\text { years }\end{array}$ & & -TEES: 8 ears & $\begin{array}{l}\text { *only the air-bone gap for TEES } \\
\text { demonstrated significant }\end{array}$ \\
\hline & & & & $\begin{array}{l}\text {-follow up for } 18.8 \text { months } \\
\text { (range } 6.7-48.3 \text { ) }\end{array}$ & improvement \\
\hline & & & & & *No complications \\
\hline & & & & & $\begin{array}{l}\text { *Both of endoscopic choleste- } \\
\text { atoma surgery and traditional } \\
\text { microscopic techniques have } \\
\text { similar hearing outcomes, rates } \\
\text { of recurrence and residual dis- } \\
\text { ease, and complications }\end{array}$ \\
\hline \multirow{4}{*}{$\begin{array}{c}\text { Kobayashi et al. } \\
\text { [35] }\end{array}$} & \multirow{4}{*}{$\begin{array}{l}\text { Retrospective case } \\
\text { review }\end{array}$} & \multirow{4}{*}{$\begin{array}{c}12 \text { children with CC } \\
\text { confined to middle ear, } \\
\text { whose age range was 1-6 } \\
\text { years }\end{array}$} & *Stage I : 7 & $\begin{array}{l}\text { Transcanal middle ear surgery } \\
\text { using endoscopes }\end{array}$ & $\begin{array}{l}\text { *The one with stage III had } \\
\text { residual diseaseduring a sec- } \\
\text { ond-look procedure }\end{array}$ \\
\hline & & & * Stage II:4 & -TEES for 12 patients & $\begin{array}{l}\text { *other patients performed one- } \\
\text { stage operation and didn't suffer } \\
\text { recurrence }\end{array}$ \\
\hline & & & *Stage III:1 & $\begin{array}{l}\text {-Microscopic surgery for } 4 \text { pa- } \\
\text { tients during the same period }\end{array}$ & $\begin{array}{l}\text { *early-stage CC can be safely } \\
\text { removed using TEES. }\end{array}$ \\
\hline & & & & $\begin{array}{l}\text { - Follow up mean duration was } \\
23.1 \text { months }\end{array}$ & \\
\hline \multirow{5}{*}{$\begin{array}{l}\text { Machironi et al. } \\
{[36]}\end{array}$} & \multirow{5}{*}{$\begin{array}{l}\text { retrospective chart } \\
\text { review }\end{array}$} & $\begin{array}{c}54 \text { children with median } \\
\text { age } 9.6 \text { years (range } \\
4-16 \text { years) }\end{array}$ & \multirow{5}{*}{$\begin{array}{l}{ }^{*} \text { Cholesteatoma } \\
\text { staging was as } \\
\text { follow; attic }(\mathrm{A}), \\
\text { tympanic cavity (T) } \\
\text { and mastoid (M) } \\
\text { sites, with a specific } \\
\text { identification of the } \\
\text { facial recess and/ } \\
\text { or sinus tympani } \\
\text { extension (S) }\end{array}$} & $\begin{array}{l}\text { TEA was performed for first } \\
\text { group }\end{array}$ & $\begin{array}{l}\text { *Recurrence rate was } 12.9 \% \\
\text { (4 ears) for the transcanal } \\
\text { endoscopic approach group and } \\
17.2 \% \text { ( } 5 \text { ears) for the canal wall } \\
\text { up microscopic approach. }\end{array}$ \\
\hline & & Divided in to 2 groups: & & $\begin{array}{l}\text {-Canal wall up microscopic } \\
\text { technique (CWU) was per- } \\
\text { formed for the second group } \\
\text { (control) }\end{array}$ & $\begin{array}{c}\text { *Residual disease was present } \\
\text { in } 26.6 \%: 19.3 \% \text { ( } 6 \text { ears) for the } \\
\text { transcanal endoscopic approach } \\
\text { group and } 34.4 \% \text { ( } 10 \text { ears) for } \\
\text { the canal wall up microscopic } \\
\text { approach. }\end{array}$ \\
\hline & & $\begin{array}{c}\text { *First group: patients } \\
\text { presenting with cho- } \\
\text { lesteatoma involving } \\
\text { the tympanic cavity } \\
\text { (mesotympanum and } \\
\text { epitympanum), attic, } \\
\text { retrotympanic and/or } \\
\text { protympanic and/or } \\
\text { hypotympanic regions, } \\
\text { with no antral/ mastoid } \\
\text { involvement }\end{array}$ & & $\begin{array}{l}\text {-Follow up mean duration was } \\
36 \text { months (range8-88) }\end{array}$ & $\begin{array}{l}\text { *Analysis at } 36 \text { months showed } \\
\text { a lower recurrence risk for the } \\
\text { transcanal endoscopic approach } \\
\text { compared with the canal wall up } \\
\text { microscopic approach, but with } \\
\text { no significance }\end{array}$ \\
\hline & & $\begin{array}{c}\text { *Second group (control): } \\
\text { patients with mastoid } \\
\text { extension of the pathol- } \\
\text { ogy }\end{array}$ & & & $\begin{array}{l}\text { *TEA represents a feasible, min- } \\
\text { imally invasive and conservative } \\
\text { technique for the management } \\
\text { of pediatric middle ear choles- } \\
\text { teatoma }\end{array}$ \\
\hline & & $\begin{array}{l}\text {-Bilateral pathology was } \\
\text { found in } 5 \text { cases, giving a } \\
\text { total of } 59 \text { ears undergo- } \\
\text { ing surgery }\end{array}$ & & & \\
\hline
\end{tabular}




\begin{tabular}{|c|c|c|c|c|c|}
\hline \multirow{3}{*}{ Kojima et al. [37] } & \multirow{3}{*}{ Case report } & \multirow{3}{*}{$\begin{array}{c}\text { One female patient } \\
\text { with } 26 \text { years old who } \\
\text { suffered hear loss in the } \\
\text { right ear }\end{array}$} & \multirow{3}{*}{-Not mentioned } & $\begin{array}{c}308 \text { and } 708 \text { rigid endoscopes } \\
\text { were used for the operation via } \\
\text { the middle cranial fossa. }\end{array}$ & $\begin{array}{l}\text { *The inferior surface of the } \\
\text { cochlea and the region around } \\
\text { the internal carotid artery could } \\
\text { be well visualized by use of } \\
\text { endoscopy }\end{array}$ \\
\hline & & & & -follow-up 3 years & $\begin{array}{l}\text { *petrous cholesteatoma sur- } \\
\text { rounding the cochlea successful } \\
\text { ly and completely removed with } \\
\text { preserving preoperative hearing }\end{array}$ \\
\hline & & & & & $\begin{array}{c}\text { *Endoscope-assisted surgical } \\
\text { technique that allowed safe and } \\
\text { complete removal of a choleste- } \\
\text { atoma extended inferior surface } \\
\text { of coclear and around carotid } \\
\text { artery in the petrous. }\end{array}$ \\
\hline
\end{tabular}

After selecting the articles according to the inclusion criteria, we reviewed the abstracts and the full articles, and we summarized them under specific titles as follow; table 1. According to publication year, there were 2 articles published in 2018 [31,32], 3 published in 2017 [29,33,34], one in 2016 [26], 2 in 2015 [35,36] and 1 in 2008 [37]. There were 6retrospective studies, one retrospective review [31], 2 retrospective case reviews [32,35], one retrospective case series [29], one retrospective chart [33], and one retrospective chart review [36], and 2 case series with chart review [26,34] and one case report $[38,39]$.

The total number of patients in this article review is 296. However, the number of ears was more than a few patients as many patients suffered bilateral disease. The age of all patients didn't exceed 18 years old, except for one study that was case report performed on the female with 26 years old [37]. There were 5 studies that didn't divide patients into groups, one included 25 children with CC and age range 17 months to 9 years [31], one included 12 children with CC with age range 2-10 years [32], one included 6 children with bilateral CC with age range 2-7 years [33] and the last one included 12 children with CC and age range 1-6 years [35].

The other 5 studies, one divided patients into 2 groups according to type of cholesteatoma into AC and CC [29], another one divided patients according to surgical strategy into inspection group and dissection group [34], another study divided patients according to strategy used for surgery into endoscopic and microscopic [26], another study divided patients according to pathology into control group and cholesteatoma group [36], the last study was case report included one female who were suffering petrous cholesteatoma [37]. The type/ classification of cholesteatoma wasn't mentioned in 4 studies [26,29,33,37], the other 5 studies mentioned the classification of cholesteatoma, 3 studies included patients with stage I, II and III [31,32,35], where patients in stage I were more dominant in the 3 studies, one study reported presence of patients with stage IV, but with more presence of patients with stage III [34], one study used the stage of cholesteatoma according to its site [36].

Regarding endoscopic strategy performed, TEES was performed for all patients in one study [31], TEES was performed for 3 patients in another study [32], for 35 cases [29], TEA was used for 6 years in one study [33] and one group of31 patients [36], TEES was performed for 8 ears [26], and 12 patients [35]. The range of follow up duration in all studies was 6.7 months-7.3 years, only one study didn't mention the exact duration of follow up, but they mentioned that the follow-up duration wasn't long [34]. The main findings and results reported that no complications occurred [26,31,32,33], recurrence occurred in one patient with stage II [31], and residual disease in one patient with stage III[35], recurrence and residual disease reported in4 studies $[26,29,34,36]$, however the lowest recurrence and residual disease rate was found in those performed endoscopy in2 studies $[29,36]$ and they were the same rate as other techniques in2studies [26,34].

The endoscopic was reported to be superior in 6 studies to manage CC successfully in pediatrics [29,31,32,33,35,36], while one study reported its successful role in visualization [29], whereas 2studies showed it wasn't superior and resulted in similar results as conventional strategies $[26,34]$. Moreover, the case report showed that endoscope assisted surgical techniques to be efficient in removing of petrous cholesteatoma [37].

\section{Discussion}

Successful of endoscopy in adults were reported in previous studies. It was reported in one study in 1995, that endoscopically assisted ear-surgery was beneficial in 9 cases and reduced the morbidity. Also, it increased the accuracy of the surgery [38]. On endoscopy evaluation, low rate of residual cholesteatoma, as well as no false negative, was reported in one study in 1997 [39]. Also, by using endoscopy as second look following primary conventional procedure showed a lower rate of residual disease than conventional methods and there was no false negative in patients undergoing endoscopic surgery [40]. The present article review was conducted to evaluate if endoscopic ear surgery can be exclusive for pediatric CC.

We reviewed nine articles; they were either retrospective reviews or case series, only one case report was included. However, this case report was for the adult with petrous cholesteatoma. The number and age of children patients were highly varied between the different studies, whereas the 
classification of cholesteatoma was too close among included studies. Several interventions were used for management of CC, either endoscopic alone, or combined with other intervention. Findings of most studies showed that endoscopy was a successful treatment for complete removal of pediatric CC.

Moreover, it was also an excellent visualization method. Only two studies showed that endoscope wasn't superior in the management of pediatric CC $[26,34]$. One study on pediatric with chronic ear problems was conducted to evaluate the accuracy of the endoscopy, and it was concluded that " open second-look mastoidectomy might be avoided if minimal or no cholesteatoma is found during the endoscopic exploration at the second look" [41]. One previous study reported the effectiveness of endoscopy approach in reducing the rate of residual cholesteatoma and improving the hearing threshold [42].

\section{Conclusion}

Endoscopic ear surgery is a useful and successful strategy for pediatric CC management. However early detection is the best way for good outcomes. No, complications for endoscopy were reported and regarding recurrence as well as residual disease, endoscopy was better to decrease the rate of both, only a few reports showed similar rates with other conventional strategies

\section{References}

1. Ayache D, Darrouzet V, Dubrulle F, Vincent C, Bobin S, et al. (2012) Imaging of non-operated cholesteatoma: clinical practice guidelines. Eur Ann Otorhinolaryngol Head Neck Dis 129: 148-152.

2. Huisman MA, De Heer E, Grote JJ (2003) Cholesteatoma epithelium is characterized by increased expression of Ki-67, p53 and p21, with minimal apoptosis. Acta Otolaryngol 123: 377-382.

3. Isaacson G (2007) Diagnosis of pediatric cholesteatoma. Paediatrics 120: 603-608.

4. Huisman MA, de Heer E, Ten Dijke P, Grote JJ (2008) Transforming growth factor beta and wound healing in human cholesteatoma. Laryngoscope 118: 94-98.

5. Preciado DA (2012) Biology of cholesteatoma: Special considerations in pediatric patients. Int J Pediatr Otorhinolaryngol 76: 319-321.

6. Semaan MT, Megerian CA (2006) The pathophysiology of cholesteatoma. Otolaryngol Clin North Am 39: 1143-59.

7. Sudhoff H, Bujia J, Holly A, Kim C, Fisseler Eckhoff A (1994) Functional characterization of middle ear mucosa residues in cholesteatoma samples. Am J Otol 15: 217-221.

8. Arsovic N, Djeric D, Petrovic Z, Djordjevic V, Krejovic Trivic S (2003) Etiopathogenetic aspects of recurrent cholesteatoma development. International Congress Series 1240: 37-42.

9. Ferlito A, Devaney KO, Rinaldo A, Milroy CM, Wenig BM, et al. (1997) Clinicopathological consultation. Ear cholesteatoma versus cholesterol granuloma. Ann Otol Rhinol Laryngol 106: 79-85.

10. Robinson JM (1997) Cholesteatoma: skin in the wrong place. J Roy Soc Med 90: 93-6.

11. Dornelles C, Costa SS, Meurer L, Schweiger C (2005) Some considerations about acquired adult and pediatric cholesteatomas. Braz J Otorhinolaryngol 71: 536-45.
12. Rutkowska J, Ozgirgin N, Olszewska E (2017) Cholesteatoma definition and classification: a literature review. The Journal of the International Advanced Otology 13(2): 266-72.

13. Yeo SW, Kim SW, Chang KH, Suh BD (2001) The clinical evaluations of pathophysiology for congenital middle ear cholesteatoma. Am J Otolaryngol 22: 184-189.

14. Warren FM, Bennett ML, Wiggins RH, Saltzman KL, Blevins KS, et al. (2007) Congenital cholesteatoma of the mastoid temporal bone. Laryngoscope 117: 1389-1394.

15. Friedberg J (1994) Congenital cholesteatoma. Laryngoscope 104: 1-23.

16. Stapleton AL, Egloff AM, Yellon RF (2012) Congenital cholesteatoma: predictors for residual disease and hearing outcomes. Arch Otolaryngol Head Neck Surg 138(3): 280-285.

17. Romanet $P$ (2001) Congenital cholesteatoma. Proceedings: $6^{\text {th }}$ International Conferenceon Cholesteatoma \& Ear Surgery 315-20.

18. Potsic WP, Samadi DS, Marsh RR, Wetmore RF (2002) A staging system for congenital cholesteatoma. Arch Otolaryngol Head Neck Surg 128(9): 1009-1012.

19. Nelson M, Roger G, Koltai PJ, et al (2002) Congenital cholesteatoma: classification, management, and outcome. Arch Otolaryngol Head Neck Surg 128(7): 810- 814.

20. Potsic WP, Korman SB, Samadi DS, Wetmore RF (2002) Congenital cholesteatoma: 20 years' experience at the Children's Hospital of Philadelphia. Otolaryngol Head Neck Surg. 126(4): 409-414.

21. Goh BS, Faizah AR, Salina H, Asma A, Saim L (2010) Congenital cholesteatoma: Delayed diagnosis and its consequences. Med J Malaysia 65(3): 189.

22. Gristwood RE, Venables WN (1982) Residual cholesteatoma. In: cholesteatoma \& Mastoid Surgery, Proceedings of the Second International Conference. Kugler Publications, Amsterdam, Netherlands, pp. 433- 38.

23. Deguine C (1978) Long Term Results in cholesteatoma Surgery. Clinic Otolaryngol 3(3): 301-10

24. Thomassin JM, Korchia D, Doris JMD (1993) Endoscopicguided otosurgery in the prevention of residual cholesteatoma. Laryngoscope 103(8): 939-43.

25. Sajjadi H (2013) Endoscopic middle ear and mastoid surgery for cholesteatoma. Iranian journal of otorhinolaryngology 25(71): 63.

26. Hunter JB, Zuniga MG, Sweeney AD, et al. (2016) Pediatric endoscopic cholesteatoma surgery. Otolaryngol Head Neck Surg 154: 1121-1127.

27. James AL, Cushing S, Papsin BC (2016) Residual cholesteatoma after endoscopeguided surgery in children. Otol Neurotol 37:196-201.

28. Kozin ED, Gulati S, Kaplan AB, et al (2015) Systematic review of outcomes following observational and operative endoscopic middle ear surgery. Laryngoscope 125: 1205-1214.

29. Ghadersohi S, Carter JM, Hoff SR. (2017) Endoscopic transcanal approach to the middle ear for management of pediatric cholesteatoma. The Laryngoscope127(11): 2653-2658.

30. Tarabichi M (1997) Endoscopic management of acquired cholesteatoma. Am J Otol 18: 544-549.

31. Park JH, Ahn J, Moon IJ (2018) Transcanal Endoscopic Ear Surgery for Congenital Cholesteatoma. Clinical and experimental otorhinolaryngology 11(4): 233.

32. Kim BJ, Kim JH, Park MK, Lee JH, Oh SH, et al. (2018) Endoscopic visualization to the anterior surface of the malleus and tensor tympani tendon in congenital cholesteatoma. European Archives of Oto-Rhino-Laryngology 275(5): 1069-1075. 
33. Marchioni D, Rubini A, Gonzalez Navarro M, Alicandri Ciufelli M, James A, et al. (2017) Bilateral congenital cholesteatoma: Surgical treatment and considerations. International journal of pediatric otorhinolaryngology 99: 146-151.

34. Cohen MS, Basonbul RA, Kozin ED, Lee DJ (2017) Residual cholesteatoma during second-look procedures following primary pediatric endoscopic ear surgery. Otolaryngology-Head and Neck Surgery 157(6) 1034-40.

35. Kobayashi T, Gyo K, Komori M, Hyodo M (2015) Efficacy and safety of transcanal endoscopic ear surgery for congenital cholesteatomas: a preliminary report. Otology \& Neurotology 36(10): 1644-50.

36. Marchioni D, Soloperto D, Rubini A, Villari D, Genovese E, et al. (2015) Endoscopic exclusive transcanal approach to the tympanic cavity cholesteatoma in pediatric patients: our experience. International journal of pediatric otorhinolaryngology 79(3): 316-22.
37. Kojima H, Tanaka Y, Yaguchi Y, Miyazaki H, Murakami S, et al. (2008) Endoscope-assisted surgery via the middle cranial fossa approach for a petrous cholesteatoma. Auris Nasus Larynx 35(4): 469-74.

38. Bottrill ID, Poe DS (1995) Endoscope-assisted ear surgery. Am J Otol 16(2): 158-63

39. Youssef TK, Poe DS (1997) Endoscope-assisted secondstage tympanomastoidectomy. Laryngoscope 107(10): 1341-4.

40. Haberkamp TJ, Tanyeri H (1999) Surgical techniques to facilitate endoscopic second look mastoidectomy. Laryngoscope 109(7): 1023-7.

41. Rosenberg SI, Silverstein H, Hoffer M, Nicholas M (1995) Use of endoscopes for chronic ear surgery in children. Arch Otolaryngol Head Neck Surg 121(8): 870-2.

42. James AL (2013) Endoscopic middle ear surgery in children. Otolaryngologic clinics of North America 46(2): 233-44.

\section{Your next submission with Juniper Publishers will reach you the below assets}

- Quality Editorial service

- Swift Peer Review

- Reprints availability

- E-prints Service

- Manuscript Podcast for convenient understanding

- Global attainment for your research

- Manuscript accessibility in different formats

( Pdf, E-pub, Full Text, Audio)

- Unceasing customer service

Track the below URL for one-step submission https://juniperpublishers.com/online-submission.php 